НАУКОВИЙ ВІСНИК

Sientific messenger of Lviv National University

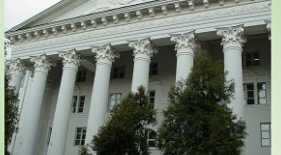

СЕРя " СІльськогосподАРСБКІ нАУКИ

Том 22 № 93

2020
Науковий вісник Дьвівського національного університету ветеринарної медицини та біотехнодогій імені С.3. Гжицького. Серія: Сільськогосподарські науки

Scientific Messenger of Lviv National University of Veterinary Medicine and Biotechnologies. Series: Agricultural sciences https://nvlvet.com.ua/index.php/agriculture

UDC 636.4:612.8

\title{
Prooxidant-antioxidant homeostasis in boars depending on the types of higher nervous activity
}

\author{
V. G. Stoianovskyi ${ }^{1}$, S. O. Usenko ${ }^{2}$, A. M. Shostya ${ }^{2}$, V. M. Sokolenko ${ }^{3}$, K. Ye. Yudina ${ }^{3}$, G. O. Birta ${ }^{4}$ \\ ${ }^{1}$ Stepan Gzhytskyi National University of Veterinary Medicin and Biotechnologies, Lviv, Ukraine \\ ${ }^{2}$ Poltava State Agrarian Academy, Poltava, Ukraine \\ ${ }^{3}$ Ukrainian Medical Stomatological Academy, Poltava, Ukraine \\ ${ }^{4}$ Poltava University of Economics and Trade, Poltava, Ukraine
}

Article info

Received 27.07.2020

Received in revised form 25.08.2020

Accepted 26.08.2020

Stepan Gzhytskyi National University of Veterinary Medicine and Biotechnologies Lviv, Pekarska Str., 50, Lviv, 79010, Ukraine. Tel.: +38-067-580-00-68 E-mail:physiology@lvet.edu.ua

Poltava State Agrarian Academy, Skovorody Str., 1/3, Poltava, 36003, Ukraine.

Tel.: +38-050-521-15-60

E-mail:sveta_usenko@ukr.net

Ukrainian Medical Stomatological Academy, Yevropeiska Str., 39, Poltava, 36011, Ukraine.

Poltava University of Economics and Trade, Kovalia Str., 3 , Poltava, 36000, Ukraine.
Stoianovskyi, V. G., Usenko, S. O., Shostya, A. M., Sokolenko, V. M., Yudina, K. Ye., \& Birta, G. O. (2020). Prooxidant-antioxidant homeostasis in boars depending on the types of higher nervous activity. Scientific Messenger of Lviv National University of Veterinary Medicine and Biotechnologies. Series: Agricultural sciences, 22(93), 3-9. doi: 10.32718/nvlvet-a9301

The peculiarities of formation of prooxidant-antioxidant homeostasis (PAG) in boars of different types of higher nervous activity have been studied. Using motor-nutritional techniques, it has been opposed adult boars of the Large White breed aged 24-36 months according to the main types of higher nervous activity (HNA). Four groups of 3 heads each were formed. The first group includes animals of a strong balanced lively (mobile) type; group II includes a strong balanced calm (inert) type; group III includes a strong unbalanced (unrestrained) type; group IV includes a weak type of higher nervous activity. Sperm was received from boars manually, taking into account the total time of ejaculation, dividing the ejaculate into 4 fractions $-F_{1}$ - the first, $F_{2}$ - the second, $F_{3}-$ the third, $F_{4}$ - the fourth. PAGs in blood and ejaculates of boars were evaluated by the intensity of peroxidation processes (xanthine oxidase, diene conjugates, TBAactive compounds) and antioxidant defense systems (superoxide dismutase, catalase, reduced glutathione, ascorbic acid, vitamin $A$ and vitamin E). Sperm contained higher amounts of diene conjugates and TBAactive complexes $(P<0.05)$ compared to blood. The second tissue relative to the first one is characterized by a higher level of antioxidant defense: catalase activity, concentration of ascorbic acid, vitamin $A$ and vitamin E. The process of PAG formation in the tissues of boars depends on the type of higher nervous activity (HNA). Thus, in individuals of a strong balanced lively and calm type, the course of peroxidation processes is somewhat slower because of a lower concentration of diene conjugates and TBA-active complexes. It was determined the fact that in blood and sperm of boars of strong unbalanced and weak types of $H N A$ the course of peroxidation is more intense, the antioxidant defense system is at a lower level that is connected with less superoxide dismutase activity $(P<0.05)$, concentration of ascorbic acid $(P<0.001)$, vitamin $A(P<0.01-0.001)$, and vitamin $E(P<0.001)$. In the second and third fractions of ejaculate of boars, the PAG is shifted in the direction of probable acceleration of peroxidation processes, especially in strong unbalanced and weak types of HNA because of a higher concentration of diene conjugates, dehydroascorbic acid. Animals of a strong balanced lively and calm types of HNA are characterized by a higher level of antioxidant defence - catalase activity, superoxide dismutase, reduced glutathione, ascorbic acid and vitamin $E$. In the first and fourth fractions of ejaculate, peroxidation processes are slower and there is no superoxide dismutase activity and the amount of vitamin $A$ and vitamin $E$.

Key words: boars, types of higher nervous activity, sperm production, blood, peroxidation, antioxidant.

\section{Прооксидантно-антиоксидантний гомеостаз у кнурів-плідників залежно від типів вищої нервової діяльності}

\author{
В. Г. Стояновський ${ }^{1}$, С. О. Усенко ${ }^{2}$, А. М. Шостя ${ }^{2}$, В. М. Соколенко ${ }^{3}$, К. Є. Юдіна ${ }^{3}$, Г. О. Бірта ${ }^{4}$ \\ ${ }^{1}$ Львівський національний університет ветеринарної медицини та біотехнологій імені С. 3. Гжицького,
}




\section{м. Львів, Украӥна}

${ }^{2}$ Полтавська державна аграрна академія, м. Полтава, Украӥна

${ }^{3}$ Украӥнська медична стоматологічна академія, м. Полтава, Украӥна

${ }^{4}$ Полтавський університет економіки і торгівлі, м. Полтава, Україна

Досліджено особливості формування прооксидантно-антиоксидантного гомеостазу (ПАГ) у кнурів-плідників різних типів вищої нервової діяльності. Використовуючи рухово-харчову методику, протиповано дорослих кнурів-плідників великої білої породи віком 24-36 місяців за основними типами вищої нервової діяльності (ВНД). Сформовано чотири групи по 3 голови в кожній. До І групи зачислено тварин сильного врівноваженого жвавого (рухливого); II групи - сильного врівноваженого спокійного (інертного); III групи - сильного неврівноваженого (нестримного); IV групи - слабкого типів вищої нервової діяльності. Сперму отримува-

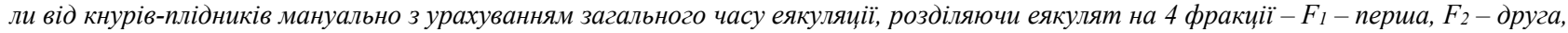
$F_{3}$ - третя, $F_{4}$ - четверта. ПАГ у крові та еякулятах кнурів-плідників оцнінювали за інтенсивністю процесів пероксидного окиснення (ксантиноксидаза, дієнові кон'югати, ТБК-активні сполуки) і системи антиоксидантного захисту (супероксиддисмутаза, каталаза, відновлений глутатіон, аскорбінова кислота, вітамін $A$ i вітамін Е). $У$ спермі виявлено вищу кількість дієнових кон'югантів та ТБК-активних комплексів (P<0,05), порівняно з кров ю. Друга тканина щуодо першої характеризується більшим рівнем антиоксидантного захисту: активністю каталази, концентрацією аскорбінової кислоти, вітаміну А і вітаміну Е. Процес формування ПАГ у тканинах кнурів-плідників залежить від типу вищої нервової діяльності. Так, в особин сильного врівноваженого жвавого і спокійного типів перебіг процесів пероксидащії дещз сповільнений - менша концентрація дієнових кон'югантів $і$ ТБКактивних комплексів. Встановлено, що у крові та спермі кнурів-плідників сильного неврівноваженого і слабкого типів ВНД перебіг прочесів пероксидаџї відбувається інтенсивніше, система антиоксидантного захисту на нижчому рівні - менша активність супероксиддисмутази $(P<0,05)$, концентрація аскорбінової кислоти $(P<0,001)$, вітаміну $A(P<0,01-0,001)$, та вітаміну E $(P<0,001)$. У другій і третій фракціях еякуляту кнурів-плідників ПАГ змішується в напрямі вірогідного прискорення процесів пер оксидації, особливо у сильного неврівноваженого і слабкого типів ВНД - більша концентрація дієнових кон 'югатів, дегідроаскорбінової кислоти. Тварини сильного врівноваженого жвавого і спокійного типів ВНД характеризуються вищим рівнем антиоксидантного захисту - активністю каталази, супероксиддисмутази, кількістю відновленого глутатіону, аскорбінової кислоти і вітаміну E. У першій $і$ четвертій фракціях еякуляту процеси пероксидаџї відбуваються повільніше та відсутні активність супероксиддисмутази, вітамін А і вітамін E.

Ключові слова: кнури-плідники, типи вищзї нервової діяльності, спермопродукція, кров, пероксидаџія, антиоксиданти.

\section{Вступ}

Інноваційний розвиток галузі тваринництва потребує розкриття і використання нових механізмів перебігу фізіологічних процесів, які відбуваються у тварин, особливо в напрямку адаптації до нових внутрішніх та зовнішніх подразників, що змінюють функції організму та $\epsilon$ необхідними для підвищення їхньої продуктивності.

Доведено, що резистентність та окремі продуктивні показники сільськогосподарських тварин обумовлюються властивостями нервової системи через особливості формуванням умовно-рефлекторної діяльності, яка змінює гомеостатичні константи (Trokoz \& Shesterynska, 2017; Kravchenko-Dovha et al., 2018; Postoi et al., 2019).

Серед головних факторів, що забезпечують ефективне ведення галузі свинарства, $є$ широке використання штучного осіменіння свиноматок. Максимальна реалізація генетичного потенціалу кнурів-плідників $\epsilon$ можливою лише при фізіологічно правильному отриманні сперми, що базується на повному проявленні статевих рефлексів, які обумовлюються особливостями вищої нервової діяльності (Evdokymov, 2013). Саме врахування індивідуальних особливостей цих тварин в період привчання і використання оператором дозволяє зменшити їхню стресочутливість за рахунок зниження рівня кортикостероїдів, що дозволяє зберігати фізіологічно нормальне протікання процесів мітозу у сім' яниках (Flowers, 2015).

Експериментами Данчука О. В. (Danchuk, 2018) доведено вплив окремих типів вищої нервової діяльності (ВНД) на формування проокидантноантиоксидантого гомеостазу у свиней різного віку за дії різних стресових чинників. Зміна даних гомеоста- тичних констант істотно впливає на якість спермопродукції, функціональну активність сперміїв та здатність їх до запліднення (Usenko et al., 2020). Коригування даних процесів шляхом додавання в корм сполук антиоксидантної дії дозволяє оптимізувати їх відтворювальну функцію. Однак часто трапляється, що у тварин дія цих сполук істотно не проявляється. Це, очевидно, обумовлено використовуваними дозами та їхніми індивідуальними особливостями, де в основі часто лежить інтенсивність протікання нервових процесів (Sysiuk et al., 2018; Postoi et al., 2019).

Однак і дотепер обсяг грунтовних літературних даних щодо особливостей формування гомеостазу у кнурів-плідників з урахуванням типологічних особливостей вищої нервової системи є вкрай обмеженим. У зв'язку з цим 3 наукової і практичної точок зору важливо дослідити вплив індивідуальних особливостей кортикальної регуляції на гомеостатичні константи в різних тканинах цих тварин.

Мета досліджень - 3'ясувати вплив типів вищої нервової діяльності на формування прооксиданоантиоксидантного гомеостазу у кнурів-плідників.

Для досягнення поставленої мети виконано такі завдання:

- визначено тип вищої нервової діяльності у кнурів-плідників;

- досліджено стан прооксидантноантиоксидантного гомеостазу (ПАГ) у крові та різних фракціях еякуляту цих тварин залежно від типів вищої нервової діяльності.

\section{Матеріал і методи досліджень}

Експерименти проведено в умовах станцій штучного осіменіння свиней Інституту свинарства і агроп- 
ромислового виробництва НААН та Державного підприємства "Дослідне господарство “Степне” ІС і АПВ HAAH".

Для визначення основних типологічних властивостей нервової діяльності у свиней використано спрощену рухово-харчову методику, пристосовану до виробничих умов, яка відповідає біологічним і фізіологічним особливостям свиней. Дана методика дає можливість визначити типологічні особливості свиней протягом 4-5 днів (Evdokymov \& Kamaldynov, 2020). Визначення типів ВНД проводили шляхом детального вивчення їхньої поведінки. Із протипованих кнурів-плідників великої білої породи віком 24 36 місяців за основними типами вищої нервової системи було сформовано чотири групи по 3 голови в кожній. I група - сильний врівноважений жвавий (рухливий); II група - сильний врівноважений спокійний (інертний); III група - сильний неврівноважений (нестримний); IV група - слабкий тип ВНД. Крім цього, звертали увагу на прояв 5 безумовних статевих рефлексів - локомоторного (зближення, статевий потяг), ерекції, обіймального і парувального.

Поранжовані кнури-плідники за типом вищої нервової діяльності мали окремі біологічні особливості. Тварини сильного врівноваженого жвавого типу характеризувались міцною конституцією, активною реакцією на зовнішні подразники з добре орієнтовним рефлексом.

Тварини врівноваженого спокійного типу мали добре розвинений кістковий і м'язовий каркас, знижена їхня рухова активність супроводжувалась ожирінням, іноді вони слабо, невміло орієнтувались у приміщенні.

Представники сильного неврівноваженого типу, маючи міцну тілобудову, добре реагували на зміни подразників зовнішнього середовища, а також у них слабко вироблялись умовні рефлекси.

Слабкий тип нервової системи був у кнурівплідників, які мали слабку конституцію, насторожено реагували на зміну незнайомої обстановки, бажали уникати помірних і сильних подразників. Ці тварини мали підвищену збудливість, швидше виснажувались при інтенсивних статевих навантаженнях.

Сперму отримували від кнурів-плідників мануально із врахуванням загального часу еяколяції, розділяючи еякулят на 4 фракції - $\mathrm{F}_{1}$ - перша, $\mathrm{F}_{2}$ - друга, $\mathrm{F}_{3}-$ третя, $\mathrm{F}_{4}$ - четверта, 3 подальшим відбором зразків. Якість сперми визначили за такими показниками: вага еякуляту, концентрація, рухливість та виживаність сперміїв згідно з Інструкцією зі штучного осіменіння (Melnyk, 2003). Режим статевого навантаження складав 2 садки на тиждень. Для уникнення гальмівних нервових процесів при виявленні статевого рефлексу у манежі зберігали умови для формування позитивних умовних рефлексів (місце отримання сперми, незмінне чучело свиноматки, один технік).

Для оцінки стану прооксидантноантиоксидантного стану в організмі кнурів-плідників аналізували кров та сперму. Інтенсивність перебігу процесів пероксидного окиснення визначали за резистентністю еритроцитів до пероксидного гемолізу (Kaidashev, 1996), активністю ксантиноксидази (КСТ) (Shabunyn, 2010), концентраціями дієнових кон'югатів (ДК) - спектрофотометрично (Havrylov \& Melkorudnaia, 1983) і ТБК-активних комплексів (альдегіди i кетони) - фотоелектроколориметрично (Kaidashev, 1996). Стан системи антиоксидантного захисту оцінювали за активностями супероксиддисмутази (СОД) (Brusov, 1976) та каталази (Koroliuk et al., 1988), кількістю відновленого глутатіону (Shabunyn, 2010), вітаміну А і вітаміну E (Kovalenko et al., 2005), аскорбінової (АК) та дегідроаскорбінової кислот (ДАК) (Kaidashev, 1996).

Отриманий цифровий матеріал статистично опрацьовували за допомогою програми Statistica для Windows XP. Для порівняння досліджуваних показників та їхніх міжгрупових різниць використовували t-критерій Ст'юдента, а результат вважали вірогідним після $\mathrm{P}<0,05$.

\section{Результати та їх обговорення}

Дані експерименту свідчать про те, що кнури із різним типом ВНД мають окремі особливості формування ПАГ у крові (табл. 1). Так, рівень пероксидної резистентності еритроцитів коливався від 7,3 до $10,5 \%$, де перший показник зареєстровано у представників сильного врівноваженого жвавого, а другий сильного неврівноваженого типів, міжгрупова різниця становила $-42,4$ \% (P < 0,05). Варто зазначити, що у особин слабкого типу порівняно із тваринами врівноваженого жвавого і спокійного типів ВНД активність КСТ була меншою відповідно у 1,6 (P < 0,001) та 1,3 разу $(\mathrm{P}<0,001)$.

Встановлено, що найбільшою концентрацією ДК характеризувались кнури-плідники III групи, яка була вищою на 16,7-36,1 \% щодо інших груп. При цьому вміст вторинних продуктів пероксидації - ТБКактивних комплексів був максимальним у тварин III і IV груп. Після інкубування зразків крові тварин у прооксидантному буфері виявлено істотне накопичення кількості цих сполук у I та II груп відповідно на 18,5 i $25,6 \%$.

У кнурів-плідників сильного жвавого типу активність СОД суттєво переважала встановлену у сильного неврівноваженого на $41 \%(\mathrm{P}<0,01)$ та слабкого типів - 34,9 \% (P < 0,05). За здатністю до знешкодження пероксиду гідрогену у порядку зростання активності каталази експериментальні тварини розподілились таким чином: III, I, IV та II групи.

Дослідження рівня відновленого глутатіону, показало, що найінтенсивніше він використовуєься кнурами-плідниками слабкого, більш повільно метаболізується у сильного неврівноваженого та врівноваженого інертного типів. При цьому максимально насиченою цією речовиною була кров тварин сильного жвавого типу. 


\section{Таблищя 1}

Прооксидантно-антиоксидантний гомеостаз у крові кнурів-плідників залежно від типу вищої нервової діяльності, $\mathrm{M} \pm \mathrm{m}, \mathrm{n}=9$

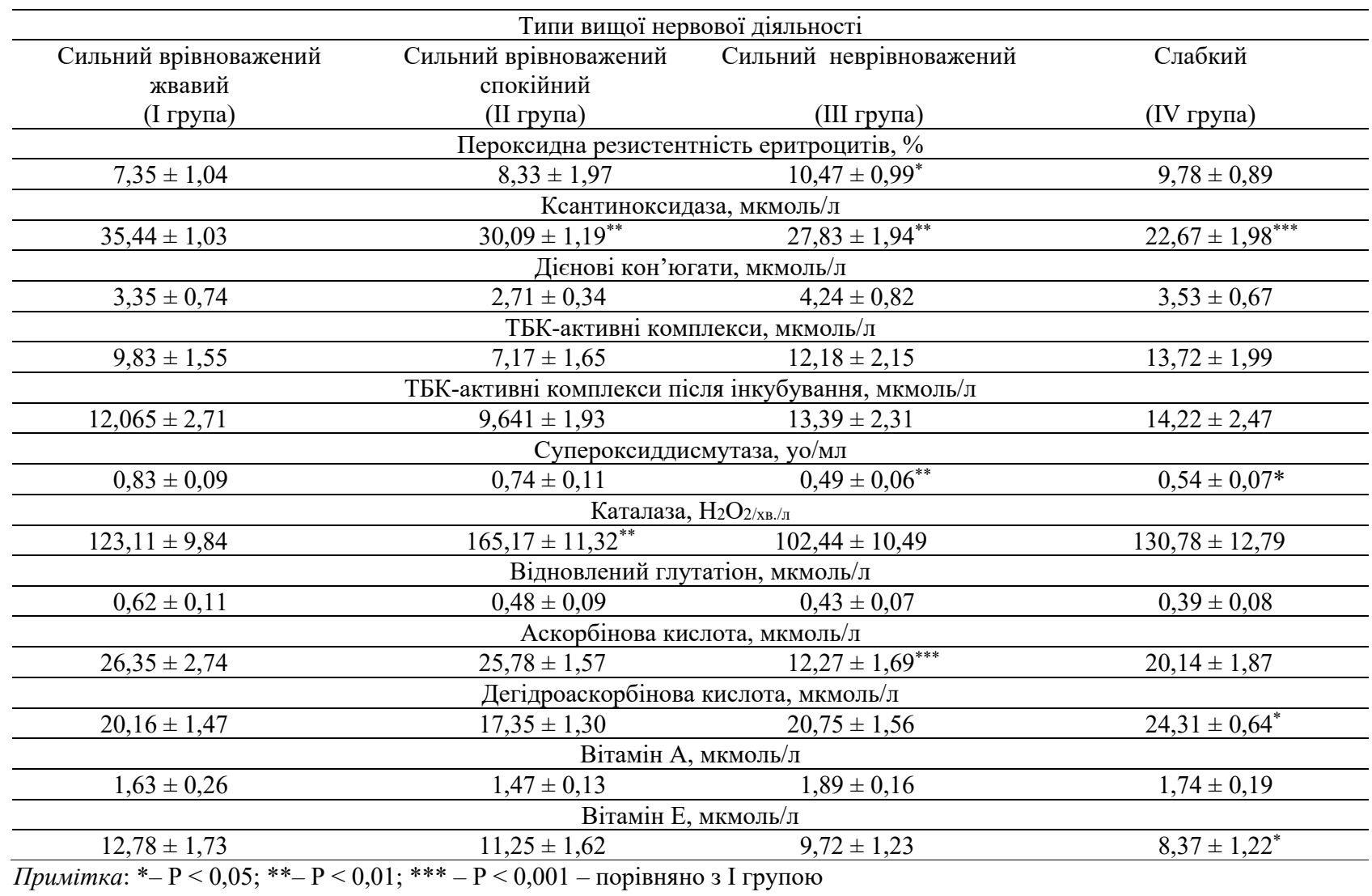

Важливим є те, що в у тварин сильного неврівноваженого типу ВНД виявлено найменшу кількість аскорбінової кислоти, в інших типів їі концентрація була вищою в межах 39,1-53,4 \%. Однак розподіл рівня окисненої форми цієї кислоти мав такі особливості: максимальний вміст відмічений у особин IV, a мінімальний - II груп, де міжгрупова різниця становила 28,6 \%. Варто зазначити, що у тварин сильного врівноваженого жвавого та спокійного типів зміна співвідношення АК до ДАК було спрямоване в напрямку переважання відновленої форми, а у особин інших типів відмічено зворотну закономірність.

Дослідження вмісту вітаміну А у крові кнурівплідників встановили незначне коливання, де найбільший його рівень було відмічено у тварин сильного неврівноваженого, а мінімальне насичення - у сильного врівноваженого інертного типів ВНД. При цьому інтенсивне використання вітаміну Е було характерним для сильного неврівноваженого та слабкого типів.

У спермі тварин сильного врівноваженого жвавого та спокійного типів ВНД насиченість дієновими кон'югантами є мінімальною, тимчасом як у сильного невріноваженого вірогідно переважала відповідно в $1,4(\mathrm{P}<0,05)$ та 1,8 разу $(\mathrm{P}<0,05)$ (табл. 2$)$. Встановлено, що найінтенсивніше процеси пероксидного окиснення протікали у тварин слабкого та сильного неврівноваженого типів, де концентрації ТБКактивних сполук істотно переважали щодо особин сильного врівноваженого спокійного відповідно на $33,8(\mathrm{P}<0,01)$ i 42,0 \% (P < 0,01). При цьому найменшою ємністю системи антиоксидантного захисту характеризувались тварини сильного врівноваженого жвавого типу, де приріст концентрації ТБК-активних сполук становив - 16,5 \%, тимсамом як у представників інших типів ВНД він сягав 21,8-37,0 \%.

У спермі виявлено вищу кількість дієнових кон'югантів та ТБК-активних комплексів $(\mathrm{P}<0,05)$ порівняно з кров’ю. Друга тканина щодо першої характеризується більшим рівнем антиоксидантного захисту: активністю каталази, концентрацією аскорбінової кислоти, вітаміну А і вітаміну Е.

Виявлено, що рівень супероксиддисмутази суттєво не відрізнявся у спермі кнурів-плідників різних типів ВНД, однак у сильного врівноваженого спокійного іiі активність була максимальною, переважаючи в інших типів у межах 24,3-31,1 \%. У тварин різних типів ВНД встановлено аналогічну закономірність розподілу активності каталази.

У спермі кнурів-плідників I і II груп вміст відновленого глутатіону переважав над встановленим у III та IV груп (табл. 3). Концентрація аскорбінової кислоти у сильного неврівноваженого і слабкого типів була вірогідно меншою ( $\mathrm{P}<0,05-0,01)$ порівняно 3 сильним врівноваженим жвавим. При цьому за кількістю окисненої форми цієї кислоти виявлено зворотну динаміку. 
Таблиця 2

Інтенсивність процесів пероксидації у спермі кнурів-плідників залежно від типу вищої нервової діяльності, $\mathrm{M} \pm \mathrm{m}$

\begin{tabular}{|c|c|c|c|}
\hline \multicolumn{4}{|c|}{ Типи вищої нервової діяльності } \\
\hline $\begin{array}{c}\text { Сильний врівноважений } \\
\text { жвавий } \\
\text { (I група) } \\
\end{array}$ & $\begin{array}{c}\text { Сильний врівноважений } \\
\text { спокійний } \\
\text { (II група) } \\
\end{array}$ & $\begin{array}{c}\text { Сильний неврівноважений } \\
\text { (III група) }\end{array}$ & $\begin{array}{l}\text { Слабкий } \\
\text { (IV група) }\end{array}$ \\
\hline \multicolumn{4}{|c|}{ Дієнові кон'югати, мкмоль/л, $\mathrm{n}=120$} \\
\hline $4,64 \pm 0,43$ & $3,79 \pm 0,38$ & $6,64 \pm 0,57^{* *}$ & $5,89 \pm 0,43^{*}$ \\
\hline \multicolumn{4}{|c|}{ ТБК-активні комплекси, мкмоль/л, n = 120} \\
\hline $18,42 \pm 1,57$ & $12,34 \pm 1,22^{* *}$ & $18,63 \pm 157$ & $21,26 \pm 1,39$ \\
\hline \multicolumn{4}{|c|}{ ТБК-активні комплекси після інкубування, мкмоль/л, $\mathrm{n}=120$} \\
\hline $22,05 \pm 1,74$ & $19,60 \pm 1,21$ & $24,96 \pm 1,49$ & $27,19 \pm 1,54^{*}$ \\
\hline \multicolumn{4}{|c|}{ Супероксиддисмутаза, у.о./мл, $\mathrm{n}=120$} \\
\hline $0,56 \pm 0,05$ & $0,74 \pm 0,07^{*}$ & $0,51 \pm 0,06$ & $0,54 \pm 0,06$ \\
\hline \multicolumn{4}{|c|}{ 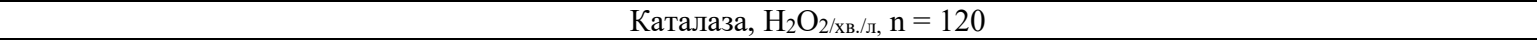 } \\
\hline $16,23 \pm 118$ & $23,57 \pm 1,15^{* * *}$ & $13,94 \pm 0,96$ & $14,45 \pm 0,97$ \\
\hline
\end{tabular}

\section{Таблиця 3}

Вміст низькомолекулярних антиоксидантів у спермі кнурів-плідників залежно від типу вищої нервової діяльності, $\mathrm{M} \pm \mathrm{m}$

\begin{tabular}{|c|c|c|c|}
\hline \multicolumn{4}{|c|}{ Типи вищої нервової діяльності } \\
\hline $\begin{array}{c}\text { Сильний врівноважений } \\
\text { жвавий } \\
\text { (I група) } \\
\end{array}$ & $\begin{array}{c}\text { Сильний врівноважений } \\
\text { спокійний } \\
\text { (II група) } \\
\end{array}$ & $\begin{array}{c}\text { Сильний неврівноважений } \\
\text { (III група) } \\
\end{array}$ & $\begin{array}{l}\text { Слабкий } \\
\text { (IV група) } \\
\end{array}$ \\
\hline \multicolumn{4}{|c|}{ Відновлений глутатіон, мкмоль/л, $\mathrm{n}=120$} \\
\hline $0,54 \pm 0,05$ & $0,43 \pm 0,048$ & $0,34 \pm 0,03^{* * *}$ & $0,33 \pm 0,03^{* * *}$ \\
\hline \multicolumn{4}{|c|}{ Аскорбінова кислота, мкмоль/л, $\mathrm{n}=120$} \\
\hline $9,12 \pm 0,90$ & $7,17 \pm 0,65$ & $5,34 \pm 0,43 * * *$ & $6,33 \pm 0,46^{* *}$ \\
\hline \multicolumn{4}{|c|}{ Дегідроаскорбінова кислота, мкмоль/л, n = 120} \\
\hline $7,64 \pm 0,67$ & $6,26 \pm 0,51$ & $8,45 \pm 0,69$ & $10,56 \pm 0,73^{* *}$ \\
\hline \multicolumn{4}{|c|}{ Вітамін А, мкмоль/л, $\mathrm{n}=60$} \\
\hline $0,96 \pm 0,13$ & $0,74 \pm 0,09$ & $1,21 \pm 0,13^{* * *}$ & $1,02 \pm 0,11$ \\
\hline \multicolumn{4}{|c|}{ Вітамін Е, мкмоль/л, $\mathrm{n}=60$} \\
\hline $2,10 \pm 0,18$ & $1,9 \pm 0,17$ & $1,47 \pm 0,21^{*}$ & $1,27 \pm 0,13^{* * *}$ \\
\hline
\end{tabular}

Встановлено, що максимальна кількість вітаміну А містилась у другій фракції еякулятів кнурів-плідників, а у третій фракції його вміст був меншим на $24,8 \%$ (I група), 12,6 \% (II група), 39,7 \% (III група) та 43,5 \% (IV група). У першій та четвертій фракціях еякуляту вітаміну А не виявлено. Загалом мінімальною кількістю вітаміну А у спермі характеризувались тварини сильного врівноваженого спокійного, а максимальною - сильного неврівноваженого типів ВНД. Аналогічний розподіл за фракціями сперми встановлений за вмістом вітаміну Е - найбільша кількість виявлена у $\mathrm{F}_{2}$ фракції, дещо меншу в $\mathrm{F}_{3}$,тимчасом як у $\mathrm{F}_{1}$ та $\mathrm{F}_{4}$ він був відсутнім. Максимальною концентрацією цього вітаміну характеризувались кнури-плідники сильного врівноваженого жвавого типу, в інших типів вміст цього вітаміну був меншим на 9,5 \% сильного врівноваженого спокійного, $30 \%(\mathrm{P}<0,05)$ сильного неврівноваженого та $39,5 \%$ (P < 0,001) слабкого.

Дослідження різних частин еякуляту показали, що у другій і третій фракціях сперми кнурів-плідників ПАГ зміщується в напрямі вірогідного прискорення процесів пероксидації, особливо в сильного неврівноваженого і слабкого типів ВНД. Тварини сильного врівноваженого жвавого і спокійного типів ВНД характеризуються вищим рівнем антиоксидантного захисту - активності каталази, супероксиддисмутази, концентрацій відновленого глутатіону, аскорбінової кислоти і вітаміну Е. У першій та четвертій фракціях еякуляту процеси пероксидації відбуваються повільніше.

Таким чином, інтенсивність процесів пероксидації у спермі на рівні утворення первинних (дієнових кон'югантів) i вторинних продуктів (ТБК-активних сполук) значно вища, ніж у крові. Це підтверджується також суттєвим приростом кількості ТБК-активних сполук після інкубування у прооксидантному буфері, що вказує на невисоку ємність системи антиоксидантного захисту у першій тканині, а також нижчою активністю каталази, насиченістю аскорбіновими кислотами, вітаміном А та вітаміном Е. Встановлена особливість формування ПАГ у спермі, очевидно, обумовлена наявністю сперміїв, значна кількість яких здатна генерувати незначні рівні радикалів Оксигену, інтенсивність цього процесу істотно зростає при їх змішуванні з секретами статевих залоз. 
Дані експерименту вказують, що на формування ПАГ у кнурів-плідників істотно впливає тип ВНД. Це обумовлено перебігом кортикальних процесів, які визначають особливості функціонування гіпоталамогіпофізарної-надниркової системи та гормонального фону (Einarsson et al., 2008). Дані фізіологічні особливості функціонування цієї системи залежно від типу вищої нервової діяльності у ссавців супроводжуються виділенням нейромедіаторів - дофаміну, мелатоніну, серотоніну та аденілциклази, які прямо регулюють процеси рухливості та капацитації сперміїв (RamírezReveco et al., 2017). Встановлений інтенсивний перебіг процесів пероксидного окиснення у спермі тварин сильного неврівноваженого і слабкого типів, очевидно, обумовлений невисоким рівнем каталази та низькомолекулярних антиоксидантів, що може супроводжуватись зниженням запліднювальної здатності сперміїв (Ramírez-Reveco et al., 2017).

Виявлена диференціація перебігу процесів пероксидного окиснення у фракціях еякуляту кнурівплідників, насамперед обумовлена різним їх біохімічним складом і фізіологічною роллю при протіканні процесів еякуляції та дозрівання сперміїв. Це насамперед полягає у відсутності активності СОД та кількості вітаміну А і вітаміну Е у першій та четвертій фракціях їх еякулятів. Різну біохімічну і фізіологічну повноцінність різних фракцій еякулятів також відмічено у дослідженнях (Torres et al., 2016; Ratchamak, 2019). Проте виявлено, що найоптимальніше формується спермопродукція в особин сильного врівноваженого жвавого та спокійного типів ВНД (Stoianovskyi et al., 2020). Істотний перебіг процесів пероксидного окиснення у другій фракції сперми обумовлений різкою зміною $\mathrm{pH}$ в напрямі лужного середовища за рахунок секретів передміхурової і цибулеподібних залоз, що забезпечуює активацію сперміїв. Ступінь розрідження сперміїв секретами статевих залоз істотно залежить від повного чи неповного їх вивільнення з сім'яників через індивідуальні особливості роботи м'язів кнурів-плідників, тонус яких може залежати від типу їхньої ВНД.

\section{Висновки}

У спермі виявлено вищу кількість дієнових кон'югантів та ТБК-активних комплексів $(\mathrm{P}<0,05)$, порівняно кров'ю. Друга тканина відносно першої характеризується більшим рівнем антиоксидантного захисту: активністю каталази, концентраціями аскорбінової кислоти, вітаміну А і вітаміну Е.

Процес формування ПАГ у тканинах кнурівплідників залежить від типу вищої нервової діяльності. Так, у особин сильного врівноваженого жвавого і спокійного типів перебіг процесів пероксидації дещо сповільнений - менша концентрація дієнових кон'югантів і ТБК-активних комплексів.

Встановлено, що у крові та спермі кнурівплідників сильного неврівноваженого і слабкого типів ВНД перебіг процесів пероксидації відбувається більш інтенсивно, система антиоксидантного захисту знаходиться на нижчому рівні - менша активність супероксиддисмутази (Р < 0,05), концентрація аскор- бінової кислоти (Р $<0,001)$, вітаміну А $(\mathrm{P}<0,01-$ $0,001)$ та вітаміну $\mathrm{E}(\mathrm{P}<0,001)$.

У другій i третій фракціях сперми кнурівплідників стан ПАГ зміщується в напрямі вірогідного прискорення процесів пероксидації, особливо у сильного неврівноваженого і слабкого типів ВНД. Тварини сильного врівноваженого жвавого і спокійного типів ВНД характеризуються вищим рівнем антиоксидантного захисту - активності каталази, супероксиддисмутази, вмісту відновленого глутатіону, аскорбінової кислоти і вітаміну Е. У першій та четвертій фракціях еякулятів процеси пероксидації відбуваються повільніше.

Подальші дослідження буде спрямовано на розкриття нових закономірностей перебігу процесів пероксидації у різних фракціях еякуляту для з'ясування причин зниження якості сперміїв у спермодозах.

\section{References}

Brusov, O. S., Herasymov, A. M., \& Panchenko, L. F. (1976). Vlyianye pryrodnikh ynhybytorov radykalnikh reaktsyi na avtookyslenye adrenalyna. Biulleten eksperymentalnoi byolohyy y medytsyni, 1, 33-35 (in Russian).

Danchuk, O. V. (2018). Peroksydne okysnennia lipidiv ta aktyvnist systemy antyoksydantnoho zakhystu $\mathrm{v}$ orhanizmi svynei z riznymy typamy vyshchoi nervovoi diialnosti: avtoref. dys. na zdobuttia nauk. stupenia d-ra vet. nauk: 03.00.13. Kyiv, 46 (in Ukrainian).

Einarsson, S., Brandt, Y., Lundeheim, N., \& Madej, A. (2008). Stress and its influence on reproduction in pigs: a review. Acta Vet Scand, 50(1), 48. doi: 10.1186/1751-0147-50-48.

Evdokymov, N. V. (2013) Selektsyonno-henetycheskye pryemi povishenyia produktyvnosty khriakov. Uchebnoe posobye. Cheboksari: Chuvashskaia HSKhA (in Russian).

Evdokymov, N. V., \& Kamaldynov, Y. N. (2020) Vosproyzvodytelnaia sposobnost khriakov s raznimy typamy visshei nervnoi deiatelnosty. Veterynarnii vrach, 1, 41-48 (in Russian).

Flowers, W. L. (2015). Factors Affecting the Efficient Production of Boar Sperm. Reprod Dom Anim, 50(2), 25-30. doi: 10.1111/rda.12529.

Havrylov, V. B., \& Melkorudnaia, M. Y. (1983). Spektrofotometrycheskoe opredelenye soderzhanyia hydroperekysei lypydov v plazme krovy. Laboratornoe delo, 3, 33-36 (in Russian).

Kaidashev, I. P. (1996). Posibnyk z eksperymentalnoklinichnykhdoslidzhen $\mathrm{z}$ biolohii ta medytsyny. Poltava, 123-128 (in Ukrainian).

Koroliuk, M. A., Yvanova, L. Y., Maiorova, Y. H., \& Tokarev E. V. (1988). Metod opredelenyia aktyvnosty katalazi. Laboratornoe delo, 1, 16-19 (in Russian).

Kovalenko, V. F., Shostia, A. M., \& Usenko, S. O. (2005). Metodyka vyznachennia vitaminiv A, E i zahalnoho kholesterynu $\mathrm{v}$ riznykh tkanynakh svynomatok plodiv. Suchasni metody v svynarstvi. za red. V.P. Rybalka. Poltava, 114-118 (in Ukrainian). 
Kravchenko-Dovha, Yu. V., Karpovskyi, V. I., Danchuk, O. V., \& Zhurenko, O. V. (2018) Mineralnyi status orhanizmu koriv riznykh typiv vyshchoi nervovoi diialnosti. Naukovyi visnyk Lvivskoho natsionalnoho universytetu veterynarnoi medytsyny ta biotekhnolohii imeni S. Z. Gzhytskoho. Seriia: Veterynarni nauky, 20(92), 109-112. doi: 10.32718/nvlvet9222 (in Ukrainian).

Li, J., Barranco, I., Tvarijonaviciute, A., \& Molina, M.F. (2018) Seminal plasma antioxidants are directly involved in boar sperm cryotolerance. Theriogenology, 107, 2735. doi: 10.1016/j.theriogenology.2017.10.035.

Melnyk, Yu. F. (2003). Instruktsiia iz shtuchnoho osimeninnia svynei. K.: Ahrarna nauka, 56 (in Ukrainian).

Postoi, R. V., Karpovskyi, V. I., \& Postoi, V. V. (2019) Vmist tryatsylhlitseroliv ta kholesterolu v krovi kholostykh svynomatok zalezhno vid osoblyvostei diialnosti nervovoi systemy. Naukovi dopovidi NUBiP Ukrainy, 5(81). doi: 10.31548/dopovidi2019.05.014 (in Ukrainian).

Postoi, R. V., Karpovskyi, V. I., Shostia, A. M., Usenko, S. O., Karunna, T. I., \& Shaferivskyi, B. S. (2019) Vplyv kortyko-vehetatyvnykh mekhanizmiv rehuliatsii na vmist laktatu, piruvatu ta yikh spivvidnoshennia u krovi svynomatok. Visnyk Poltavskoi derzhavnoi ahrarnoi akademii, 4, 205-211. doi: 10.31548/dopovidi2019.05.014 (in Ukrainian).

Ramírez, A. R., Castro, M. A., Angulo, C., Ramió, L., Rivera, M. M., Torres, M., Rigau, T., RodríguezGil, J. E., Concha, I. I. (2009). The Presence and Function of Dopamine Type 2 Receptors in Boar Sperm: A Possible Role for Dopamine in Viability, Capacitation, and Modulation of Sperm Motility. Biology of Reproduction, 80(4), 753-761. doi: 10.1095/biolreprod.108.070961.

Ramírez-Reveco, A., Villarroel-Espíndola, F., RodríguezGil, J. E., \& Concha, I. I. (2017). Neuronal signaling repertoire in the mammalian sperm functionality. Biology of Reproduction, 96(3), 505-524. doi: 10.1095/biolreprod.116.144154.
Ratchamak, R., Vongpralub, T., Boonkum, W., \& Chankitisaku, V. (2019). Cryopreservation and quality assessment of boar semen collected from bulk samples. Veterinarni Medicina, 64(05), 209-216. doi: 10.17221/125/2018-VETMED.

Shabunyn, S. V. (2010). Metodycheskie polozhenyia po izucheniyu protsessov svobodnoradykalnoho okisleniya $\mathrm{V}$ sisteme antioksydantnoi zashchity orhanyzma. Voronezh, 36-37; 51-52 (in Russian).

Stoianovskyi, V. H., Usenko, S. O., Shostia, A. M., Hyria, V. M., Sokyrko, M. P., Vasylieva, O. O., \& Bereznytskyi, V. I. (2020). Yakist spermoproduktsii u knuriv-plidnykiv zalezhno vid typiv vyshchoi nervovoi diialnosti. Agrarian Bulletin of tte Black Sea Littoral, 97, 14-23. doi: 10.37000/abbsl.2020.97.02 (in Ukrainian).

Sysiuk, Yu. O., Kravchenko-Dovha, Yu. V., Karpovskyi, V. I., Danchuk, O. V., \& Zhurenko, O. V. (2018). Vplyv typu vyshchoi nervovoi diialnosti na aktyvnist superoksyddysmutazy ta vmist kuprumu i tsynku $\mathrm{v}$ krovi koriv. Biolohiia tvaryn: naukovo-teoretychnyi zhurnal, 2(4), 55-60. doi: 10.31210/visnyk2019.04.26 (in Ukrainian).

Torres, M. A., Ravagnani, G. M., \& Leal, D. F. (2016). Seminal plasma arising from the whole boar spermrich fraction increases the stability of sperm membrane after thawing. American Society of Animal Science, 94, 1906-1912. doi: 10.2527/jas.2016-0293.

Trokoz, V. O., \& Shesterynska, V. V. (2017). Osoblyvosti obminu vuhlevodiv u svynei riznykh typiv vyshchoi nervovoi diialnosti: Monohrafiia. Kyiv: Ekspo-druk (in Ukrainian).

Usenko, S. O., Shostia, A. M., Stoianovskyi, V. H., Birta, H. O., Kuzmenko, L. M., \& Slynko, V. H. (2020). Prooksydantno-antyoksydantnyi homeostaz V inkubovanii spermi knuriv-plidnykiv pry zghodovuvanni laktativ mikroelementiv. Naukovi dopovidi NUBiP, 29(84). doi: 10.31548/dopovidi2020.02.017 (in Ukrainian). 